\title{
Educação do corpo e do gênero: histórias, discursos e práticas
}

\author{
Avelino Aldo de Lima Neto \\ IFRN, Natal, RN, Brasil \\ Azemar dos Santos Soares Juniorii \\ UFRN, Natal, RN, Brasil \\ Lucélia de Moraes Braga Bassaloiii \\ UEPA, Belém, PA, Brasil
}

\section{Apresentação}

Como a educação é atravessada pelos conceitos de corpo e gênero? Ou como a educação atravessa os corpos? A resposta a essas questões são amplas já que a educação é um processo social que se delineia a partir das relações que se estabelecem entre os indivíduos no decurso de suas vidas materiais. É ao longo de aprendizagens sociais sobre ser, sentir e fazer, enquanto sujeitos em um determinado contexto, que a educação se inscreve, constrói ou pode desconstruir, sentidos e significados do feminino, do masculino e seus atravessamentos. Revelar nas tramas dos conceitos de corpo e de gênero as linhas educativas dos modos de aprender a estar no mundo como corpo generificado move a iniciativa de reunir pesquisadores de áreas, recortes teóricos e metodológicos distintos para refletir em oito artigos sobre a educação do corpo, a educação do gênero nesse dossiê, intitulado Educação do corpo e do gênero: histórias, discursos e práticas.

Partimos do pressuposto segundo o qual a dispersão do corpo no interior das Ciências Humanas e Sociais (ANDRIEU, 1993) permite uma miríade de abordagens teórico-metodológicas que tentam, sem cessar, dar conta da polissemia da existência incorporada. O presente dossiê traz à tona essa experiência multifacetada, pensando-a a partir dos processos sociohistóricos por meio dos quais o sujeito opera sobre si, enquanto corpo, variadas técnicas com vistas a se inserir numa dada cultura (MAUSS, 2003). A esse fenômeno chamamos de educação, seja ela formal ou informal, escolar ou não-escolar.

Inscrita no corpo, a educação altera e produz sensibilidades (CORBIN, 1987), adestra gestos e posturas, organiza espaços e tempos (VIGARELLO, 2018), bem como racionaliza e instrumentaliza o corpo (GLEYSE, 2018). Ela pode também proporcionar ao

Educação \& Formação, Fortaleza, v. 6, n. 2, e5512, 2021

DOI: https://doi.org/10.25053/redufor.v6i2.5512

https://revistas.uece.br/index.php/redufor/index

ISSN: 2448-3583 
indivíduo organizar o conhecimento do mundo a partir do sentir mesmo, isto é, de uma estesiologia (NÓBREGA, 2018). A educação, nesse sentido, está profundamente imbricada com a fabricação social do corpo na estesia da vida cotidiana (LE BRETON, 2016), a qual, evidentemente, não está desvinculada das operações de generificação da corporeidade. Ser homem ou mulher implica ocupar uma posição na ordem do discurso, na referência ao sexo enquanto norma/prática regulatória produtora dos corpos por ela controlada (BUTLER, 2019). A construção das identidades reflete diretamente no e sobre o corpo (FOUCAULT, 2009). São formas de poder responsáveis por atribuir sentido aquilo que historicamente foi legado à condição de estranhamento. O corpo torna-se aquilo que a identidade sonha, deseja, se constrói.

À maneira foucaultiana, diagnosticamos a emergência dessas experiências compreendidas enquanto "alguma coisa da qual saímos transformados" (FOUCAULT, 2001, p. 860) - de ser corpo generificado, por meio da conjunção de histórias, discursos e práticas. Os artigos que compõem o presente dossiê testemunham esse entrelaçamento, numa escansão histórica cujo arquivo abarca experiências vividas de fins do século XIX aos nossos dias, imagens de um "corpo educado" (LOURO, 2010), abordado a partir de diferentes olhares disciplinares.

Pomos em tela, assim, os seguintes temas: a generificação das punições escolares em instituições francesas; as pedagogias feministas em grupos de humanização do parto em Belém/PA; uma abordagem filosófica sobre educação sexual; discursos sobre a assim chamada "ideologia de gênero" em municípios paraibanos; processos de subjetivação de homens docentes; compreensões sobre o corpo na formação docente; a maternidade no Ceará oitocentista; igualdade entre os gêneros na educação francesa; práticas de masturbação e as pedagogias em torno do prazer em uma instituição socioeducativa de Salvador/BA. Também tivemos a satisfação de incluir no dossiê a tradução de um texto inédito de Judith Butler no Brasil. Nessa ocasião, a filósofa estadunidense estuda a análise de Luce Irigaray sobre certos aspectos da fenomenologia de Merleau-Ponty. Portanto, de modo arbitrariamente heterogêneo, entra em cena o próprio corpo em seus jogos políticos, no "circuito dos afetos" (SAFATLE, 2016) sem o qual organizar-se socialmente seria

Educação \& Formação, Fortaleza, v. 6, n. 2, e5512, 2021

DOI: https://doi.org/10.25053/redufor.v6i2.5512

https://revistas.uece.br/index.php/redufor/index

ISSN: 2448-3583 
impossível, dada a economia libidinal do vínculo societal das democracias contemporâneas.

Por fim, ressaltamos que o presente dossiê é manifestação de intensas parcerias internacionais entre pesquisadores(as) e grupos de pesquisa de Instituições de Ensino Superior brasileiras e francesas ao longo dos últimos anos, fruto de acordo de cooperação celebrado entre o IFRN, a UFRN e a Universidade de Montpellier. Mais recentemente, integra-se a essa iniciativa a Universidade do Estado do Pará, através do PROCADAmazônia do qual os Programas de Pós-Graduação em Educação da UFRN e da UEPA fazem parte. Espera-se contribuir, com a presente iniciativa, na difusão dos investimentos em torno das múltiplas maneiras de dizer, ver e sentir o corpo.

\section{Referências}

ANDRIEU, Bernard. Le corps dispersé: histoire du corps au XXe siècle. Paris: L'Harmattan, 1993.

BUTLER, Judith. Corpos que importam: os limites discursivos do sexo. Tradução de Verônica Daminelli e Daniel Yago Françoli. S]ao Paulo: N-1 edições, Crocodilo, 2019.

CORBIN, Alain. Saberes e Odores: o olfato e o imaginário social nos séculos XVIII e XIX. Tradução de Lígia Watanabe. São Paulo: Cia. das Letras, 1987.

FOUCAULT, Michel. Entretien avec Michel Foucault. In : FOUCAULT, Michel. Dits et Écrits II: 1976-1988. Paris: Gallimard, 2001.

GLEYSE, Jacques. A instrumentalização do corpo: uma arqueologia da racionalização instrumental do corpo, da Idade Clássica à Época Hipermoderna. Tradução de Avelino Aldo de Lima Neto, Cláudia Emília Aguiar Moraes e Fábio Luís Santos Teixeira. São Paulo: LiberArs, 2018.

LE BRETON, David. Antropologia do Corpo. Tradução de Fábio dos Santos Creder Lopes. Petrópolis: Vozes, 2016.

LOURO, Guacira Lopes (org.). O corpo educado: pedagogias da sexualidade. Belo Horizonte: Autêntica, 2010.

MAUSS, Marcel. As técnicas do corpo. In: MAUSS, Marcel. Sociologia e Antropologia. Tradução de Paulo Neves. São Paulo: Cosac Naif, 2003. 
NÓBREGA, Terezinha Petrucia. Uma estesiologia do corpo... In: NÓBREGA, Terezinha Petrucia (org.). Estesia: corpo, fenomenologia e movimento. São Paulo: LiberArs, 2018.

SAFATLE, Vladimir. O circuito dos afetos: corpos políticos, desamparo e o fim do indivíduo. Belo Horizonte: Autêntica, 2016.

VIGARELLO, Georges. Le Corps redressé : Histoire d'un pouvoir pédagogique. Paris : Félin, 2018.

\section{' Avelino Aldo de Lima Neto, ORCID: https://orcid.org/0000-0003-4810-8742}

IFRN, Programas de Pós-Graduação em Educação Profissional (PPGEP/IFRN) e em Educação (PPGEd/UFRN), Doutor em Ciências da Educação pela Universidade Paul Valéry - Montpellier III e Contribuição de autoria: escrita coletiva do texto. pela UFRN

Lattes: http://lattes.cnpq.br/3231870235953025

E-mail: ave.neto@hotmail.com

i Azemar dos Santos Soares Junior, ORCID: https://orcid.org/0000-0003-0015-415X

UFRN, Programas de Pós-Graduação em Educação (PPGEd/UFRN) e em História (PPGH/UFCG)

Sócio efetivo do Instituto Histórico e Geográfico do Rio Grande do Norte (IHGRN), Doutor em

Educação pela Universidade Federal da Paraíba

Contribuição de autoria: escrita coletiva do texto.

Lattes: http://lattes.cnpq.br/5548182860228173

E-mail: azemarsoares@hotmail.com

' Lucélia de Moraes Braga Bassalo, ORCID: https://orcid.org/0000-0002-0412-6052

Universidade do Estado do Pará (UEPA), Programa de Pós-Graduação em Educação

(PPGED/UEPA), Doutora em Educação pela Universidade de Brasília

Contribuição de autoria: escrita coletiva do texto.

Lattes: http://lattes.cnpq.br/6941089571024585.

E-mail: lucelia.bassalo@uepa.br

Editora responsável: Lia Machado Fiuza Fialho

\section{Como citar este artigo (ABNT):}

LIMA NETO, Avelino A. de; SOARES JÚNIOR, Azemar dos S.; BASSALO, Lucélia de M. B. Educação do corpo e do gênero: histórias, discursos e práticas. Educ. Form., Fortaleza, v. 6, n. 2, e5512, 2021. 